\title{
ANALISIS PENGARUH INTERKONEKSI DISTRIBUTED GENERATION (PLTSA SUWUNG) TERHADAP RUGI-RUGI DAYA DAN KEANDALAN PADA PENYULANG SERANGAN
}

\author{
I Made Gusmara Nusaman. ${ }^{1}$, I Wayan Sukerayasa ${ }^{2}$, Rukmi Sari Hartati ${ }^{3}$
}

\begin{abstract}
The distributed generation technology or in this case abbreviated DG is a kind of power plants with small scale which prioritizes the utilization of renewable energy resources such as wind, water, solar, geothermal, ocean waves (Wave Energy), ocean currents (Ocean Current Energy), biomass, and biogass to produce the electrical energy with range of power generation between $1 \mathrm{~kW}-10 \mathrm{MW}$. One of the DG in Bali and still in operation is the garbage power plant which located in Suwung, South Denpasar. An analysis has been done using load flow analysis and reliability assessment to determine the effect of DG interconnection against the power losses and the level of reliability on the Serangan feeder. Based on the research that has been done, DG intercon-nection on the Serangan feeder decrease the power losses and increase the reliability and it can visible from the acquisition of SAIFI and SAIDI index which decreased. The best location of DG interconnection to get low of the power losses and the high level of reliability is at $97 \%$ from the total length of the feeder. At that location the power losses is decrease as big as $4.5 \mathrm{~kW}$ or $11.25 \%$ of the total power lossess without the DG interconnection and decrease of the SAIFI and SAIDI index respectively to 0.1 failure/customers/year and 1.4150 hour/ customer/year
\end{abstract}

Intisari - Teknologi Distributed Generation atau dalam hal ini disingkat DG merupakan jenis pembangkit listrik dengan skala kecil yang mengutamakan pemanfaatan sumber energi terbarukan seperti angin, air, matahari, panas bumi, gelombang laut (Wave Energy), arus laut (Ocean Current Energy), biomassa, dan biogas dengan daya keluaran DG antara $1 \mathrm{~kW}$ sampai $10 \mathrm{MW}$.

\footnotetext{
Mahasiswa, Teknik Elektro dan Komputer Universitas Udayana, Kampus Bukit Jimbaran, Badung Bali. 80361, Tel. 0361703315 fax:0361703315; e-mail: igakdiafari@yahoo.com

${ }^{2}$ Dosen Teknik Elektro dan Komputer Universitas Udayana, Kampus Bukit Jimbaran, Badung Bali. 80361, Tel. 0361703315 fax: 0361703315; e-mail: sukerayasa@unud.ac.id

${ }^{3}$ Dosen Teknik Elektro dan Komputer Universitas Udayana, Kampus Bukit Jimbaran, Badung Bali. 80361, Tel. 0361703315 fax:0361703315; e-mail:rshartati@unud.ac.id
}

.Salah satu DG yang ada di Bali dan saat ini masih beroperasi adalah Pembangkit Listrik Tenaga Sampah (PLTSa) yang berada di daerah Suwung, Denpasar selatan. Analisis pengaruh interkoneksi DG terhadap rugi-rugi daya dan tingkat keandalan pada Penyulang Serangan menggunakan simulasi aliran daya (load flow analysis) dan reliability assessment. Berdasarkan penelitian yang telah dilakukan, diperoleh hasil yaitu dengan interkoneksi DG pada Penyulang Serangan terjadi penurunan rugi-rugi daya dan peningkatan keandalan yang terlihat dari perolehan nilai indeks SAIFI dan SAIDI yang menurun. Lokasi interkoneksi terbaik untuk memperoleh rugi-rugi daya yang rendah dan tingkat keandalan yang tinggi adalah pada jarak $97 \%$ dari total panjang saluran. Pada lokasi tersebut diperoleh penurunan rugi-rugi daya sebesar $4,5 \mathrm{~kW}$ atau $11,25 \%$ dari total rugi-rugi daya tanpa interkoneksi DG serta penurunan indeks SAIFI dan SAIDI masing-masing menjadi 0,1 gangguan/pelanggan/tahun dan 1,4150 jam/ pelanggan/tahun.

Kata Kunci: Rugi-Rugi Daya, Keandalan, Load Flow , Analysis, Reliability Assessment

\section{PENDAHULUAN}

Teknologi Distributed Generation atau DG merupakan pengembangan teknologi sistem tenaga listrik dengan skala kecil yang mengutamakan pemanfaatan sumber-sumber energi terbarukan (Renewable Energy) yang ramah lingkungan, berkelanjutan (sustainable), dan ekonomis seperti angin, air, matahari, panas bumi, gelombang laut (Wave Energy), arus laut (Ocean Current Energy), biomassa, dan biogas untuk menghasilkan energi listrik dengan kisaran daya yang dihasilkan antara $1 \mathrm{~kW}-10 \mathrm{MW}$.

PLTSa Suwung merupakan sebuah pembangkit listrik tenaga sampah (PLTSa) yang berlokasi di TPA Suwung dan dapat disebut sebagai sebuah DG yang sampai saat ini masih beroperasi dalam sistem distribusi tenaga listrik di Bali. Pembangunan pembangkit listrik tersebut diprakarsai oleh Pemerintah Kota Denpasar, Pemerintah Kabupaten Badung, Gianyar, dan Tabanan yang terin-tegrasi dalam Badan Pengelola Kebersihan SARBAGITA yang bekerjasama dengan PT. Navigat Organic Energy Indonesia (NOEI) dan PT. PLN Distribusi Bali. 
Dalam penelitian ini telah dilakukan analisis pengaruh pengalihan interkoneksi DG sebagai alternatif baru untuk mengurangi rugi-rugi daya dan meningkatkan keandalan pada salah satu penyulang. DG yang sebelumnya terinterkoneksi ke busbar $20 \mathrm{kV}$ Transformator V GI Pesanggaran disimulasikan dalam kondisi terinterkoneksi ke Penyulang Serangan yang merupakan penyulang terdekat dari lokasi DG. Untuk memperoleh hasil berupa penurunan rugi-rugi daya dan peningkatan keandalan pada sistem distribusi tenaga listrik yang dianalisis, maka dibuat sebuah simulasi Load Flow Analysis dan Reliability Assessment.

\section{II.DISTRIBUTED GENERATION (DG)}

DG merupakan pembangkit skala kecil dengan kisaran daya yang dihasilkan antara $1 \mathrm{~kW}$ sampai dengan $10 \mathrm{MW}$. Teknologi DG sangat diperlukan di sisi jaringan distribusi karena sistem tersebut dapat mengurangi rugi-rugi daya pada sistem dan memperbaiki kualitas tegangan untuk terciptanya keandalan sistem tenaga listrik [1]. Berikut adalah contoh interkoneksi DG pada jaringan distribusi tenaga listrik.

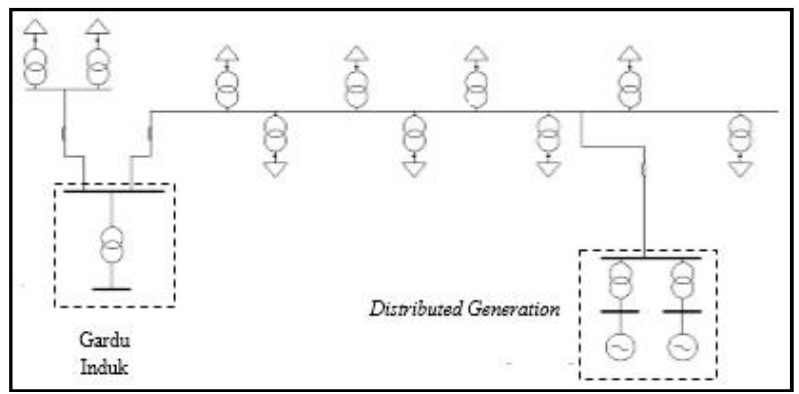

Gambar 1. Interkoneksi DG pada Jaringan Distribusi Tenaga Listrik

DG memiliki fungsi utama yaitu sebagai unit yang difungsikan untuk mengantisipasi apabila terjadi pemutusan dari suplai daya grid atau stand by unit dan difungsikan sebagai unit yang dipasang pada jam-jam beban puncak atau peaking unit [2]. Berikut penggolongan tipe DG berdasarkan range daya yang mampu dihasilkan.

Tabel 1. Tipe DG Berdasarkan Range Daya Yang Dihasilkan

\begin{tabular}{|l|l|}
\hline \multicolumn{1}{|c|}{ Tipe DG } & \multicolumn{1}{c|}{ Range Daya } \\
\hline Micro $D G$ & 1 watt $<5 \mathrm{~kW}$ \\
\hline Small $D G$ & $5 \mathrm{~kW}<5 \mathrm{MW}$ \\
\hline Medium $D G$ & $\begin{array}{l}5 \mathrm{MW}<50 \\
\mathrm{MW}\end{array}$ \\
\hline Large $D G$ & $<300 \mathrm{MW}$ \\
\hline
\end{tabular}

\subsection{Analisis Aliran Daya}

Load flow analysis atau analisis aliran daya merupakan sebuah analisis yang dilakukan untuk melihat kemampuan atau performa suatu sistem tenaga listrik. Tujuan dari analisis aliran daya adalah untuk mengetahui apakah jaringan atau sistem distribusi tidak mengalami over load dan tegangan sistem masih berada pada standar yang ditentukan. Selain itu studi aliran daya dilakukan untuk mengetahui aliran daya aktif dan reaktif pada jaringan serta untuk mengetahui besarnya rugi-rugi daya yang terjadi selama proses pendistribusian daya [3]. Dengan matriks $Y_{\text {bus }}$, dapat dibuat persamaan untuk sebuah jaringan sistem tenaga listrik sebagai berikut [4]:

$$
I=Y_{\text {bus }} V
$$

Dimana $I$ merupakan vektor ke $N$ dari sumber arus yang di injeksi ke setiap bus dan $V$ adalah vektro ke $N$ dari tegangan bus. Persamaan arus yang mengalir pada bus k:

$I_{k}=\sum_{n=1}^{N} Y_{k n} V_{n}^{\prime}$

Daya kompleks pada bus $k$ tersebut adalah:

$S_{k}=p_{k}+j Q_{k}=V_{k} I_{k}^{*}$

Dengan memasukkan Persamaan (2) ke Persamaan (3) akan menghasilkan:

$P_{k}+j Q_{k}=V_{k} \sum_{n=1}^{N} Y_{k n} V_{n}^{*} \quad k=1,2, \ldots N$

Dengan persamaan berikut:

$V_{n}^{\prime}=V_{n}^{\prime} e^{j \delta_{n}}$

$$
Y_{k n}=Y_{k n} e^{j \theta_{k n}}=G_{k n}+j B_{k n}
$$

$$
k, n=1,2, \ldots, N
$$

Maka persamaan (4) menjadi

$F_{k}+j Q_{k}=V_{k} \sum_{n=1}^{N} Y_{k n} V_{n}^{\prime} e^{j\left(\delta_{k-} \delta_{n-} \theta_{k n}\right)}$

Jika bagian real dan imajiner pada persamaan (4) di pisahkan dan dinyatakan dalam bentuk rektangular maka

$$
\begin{gathered}
P_{k}=V_{k} \sum_{q=1}^{n} V_{n}^{\prime} G_{k n} \cos \delta_{k}-\delta_{n}+B_{k n} \sin \delta_{k}-\delta_{n} \\
Q_{k}=V_{k} \sum_{q=1}^{n} V_{k} G_{k n} \sin \delta_{k}-\delta_{n}-B_{k n} \cos \delta_{k}-\delta_{n}
\end{gathered}
$$

\subsection{Keandalan Sistem Distribusi Tenaga Listrik}

Keandalan (reliability) didefinisikan se-bagai peluang suatu komponen atau sistem memenuhi fungsi yang dibutuhkan dalam periode waktu yang diberikan selama digunakan dalam kondisi beroperasi. Indeks keandalan dapat direpresentasikan menggunakan teori probabilitas dengan menggunakan pendekatan berupa rumus matematis, yang tergantung pada masalah dan asumsi peralatan. Keandalan penyulang tergantung dari konfigurasi, jumlah komponen, serta jumlah pelanggan. Evaluasi keandalan sistem distribusi terdiri dari indeks titik beban dan indeks sistem yang dipakai untuk memperoleh pengertian yang mendalam pada keseluruhan capaian. Indeks kegagalan titik beban yang biasanya digunakan meliputi tingkat kegagalan (Kegagalan/Tahun), rata-rata waktu keluar (outage) $r$ (Jam) dan rata-rata ketaktersediaan tahunan $U$ (Jam/Tahun) [5]. Indeks keandalan yang digunakan untuk menggambarkan tingkat keandalan jaringan dapat dinyatakan dalam persamaan-persamaan berikut:

\section{A. SAIFI (System Average Interruption Frequency Index)}

SAIFI merupakan indeks frekuensi gangguan sistem rata-rata setiap tahun. Menginformasikan tentang frekuensi gangguan rata-rata setiap konsumen dalam suatu area yang dievaluasi. Indeks SAIFI dirumuskan dengan [6]:

$$
\mathrm{SAIFI}=\frac{\sum N_{i}}{N_{T}}
$$


Dengan $N_{\mathrm{i}}$ adalah jumlah gangguan pada pelanggan dan $N_{T}$ adalah jumlah total pelanggan yang dilayani pada area yang mengalami gangguan.

\section{B. SAIDI (System Average Interruption Duration Index)}

SAIDI adalah indeks keandalan yang merupakan jumlah dari perkalian lama padam dan pelanggan padam dibagi dengan jumlah pelanggan yang dilayani. Indeks SAIDI dirumuskan dengan [6]:

$$
\text { SAIDI }=\frac{\sum r_{i} N_{i}}{N_{T}}
$$

Dengan $r_{i}$ merupakan waktu penormalan gangguan untuk setiap gangguan yang terjadi

\section{CAIDI (Customer Average Interruption Duration Index)}

Indeks ini menggambarkan lama waktu (durasi) rata-rata setiap pemadaman. Indeks ini merupakan perbandingan antara SAIDI dan SAIFI yang dirumuskan dengan [6]:

$$
\text { CAIDI }=\frac{\sum r_{i} x N_{i}}{\sum N_{i}}=\frac{\text { SAIDI }}{\text { SAIFI }}
$$

Besarnya nilai CAIDI ini dapat digambarkan sebagai besarnya durasi pemadaman sistem distribusi keseluruhan ditinjau dari sisi pelanggan.

\section{ASAI (Average ServiceAvailability Index)}

Indeks ini menggambarkan tingkat ketersediaan layanan (Suplai daya) yang diterima oleh pelanggan. Indeks ini dirumuskan dengan [6]:

$$
\mathrm{ASAI}=\frac{N_{T} \times 8760-\sum r_{\underline{i}} N_{i}}{N_{T} \times 8760}
$$

Dengan 8760 adalah total jumlah jam dalam satu tahun kalender.

\section{E. ASUI (Average ServiceUnvailability Index)}

Indeks ini menggambarkan tingkat ketersediaan layanan (Suplai daya) yang diterima oleh pelanggan, dengan rumus [6]:

$$
\mathrm{ASUI}=\frac{\sum r_{i} N_{i}}{N_{T} \times 8760}
$$

\section{METODE}

Penelitian mengenai pengaruh interko-neksi DG terhadap rugi-rugi daya dan keandalan bertempat di PT. PLN (Persero) Distribusi Bali Area Bali Selatan dengan tujuan memperoleh data-data penunjang penelitian dan waktu pelaksanaannya dimulai pada bulan Juni 2015. Analisis pengaruh interkoneksi DG terhadap rugi-rugi daya dan keandalan pada Penyulang Serangan dibuat dalam sebuah simulasi load flow analysis dan reliability assessment. Dalam analisis pengaruh interkoneksi DG terhadap rugi-rugi daya dan keandalan pada Penyulang Serangan diperlukan data-data sebagai berikut:
a. Single line diagram Penyulang Serangan
b. Data rating dan beban transformator
c. Data beban puncak Penyulang Serangan
d. Data penghantar
e. Data output daya DG (PLTSa Suwung)
f. Data jumlah pelanggan penyulang

Analisis diawali dengan menggambar ulang single line diagram Penyulang Serangan dan menginputkan data-data yang diperukan dalam simulasi serta analisis rugi-rugi daya dan keandalan seperti rating transformator, beban puncak dari setiap transformator, jenis penghantar, panjang penghantar, impedansi penghantar, dan rating daya dari DG. Untuk mengetahui aliran daya dan rugi-rugi daya yang terjadi pada Penyulang Serangan menggunakan Load Flow Analysis, sedangkan untuk mengetahui tingkat keandalan Penyulang Serangan menggunakan Reliability Assessment. Analisis rugirugi daya dan keandalan dilakukan dalam 2 kondisi yaitu Penyulang Serangan tanpa interkoneksi DG dan kondisi Penyulang Serangan dengan interkoneksi DG. Pengujian pengaruh DG yang diinterkoneksikan pada penyulang dilakukan pada beberapa titik $(25 \%, 50 \%, 75 \%, 80 \%-90 \%$, dan $90 \%-100 \%$ ) untuk mengetahui titik interkoneksi dengan nilai rugi-rugi yang rendah dan tingkat keandalan yang tinggi. Pengaruh interkoneksi DG terhadap rugi-rugi daya dan keandalan ditampilkan dalam bentuk tabel dan grafik untuk melihat pola penurunan rugi-rugi daya dan peningkatan keandalan dari setiap titik lokasi interkoneks DG. Tahapan analisis tersebut dapat dilihat pada diagram alur analisis pada gambar 2 berikut:

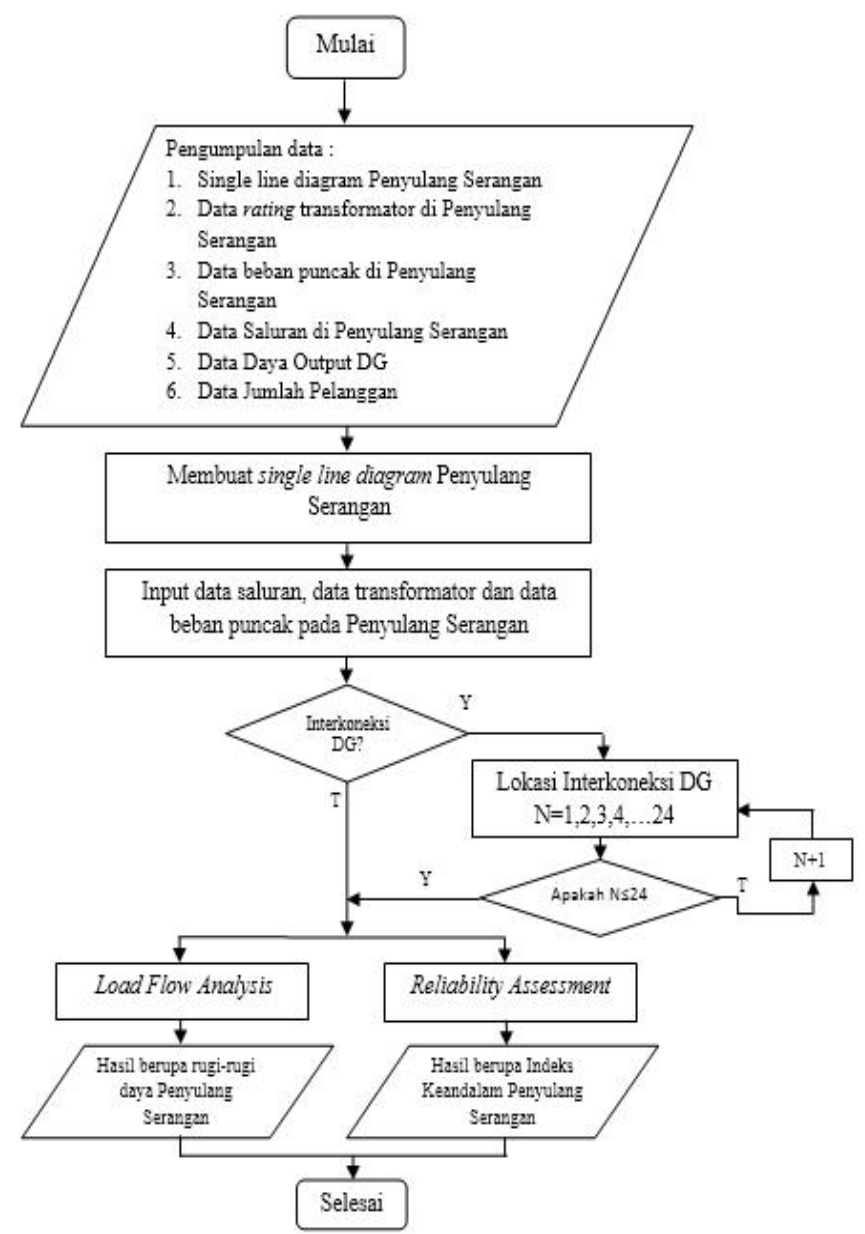

Gambar 2. Alur Analisis Rugi-Rugi Daya dan Keandalan 


\section{HASIL DAN ANALISIS}

Penyulang Serangan merupakan jaringan distribusi tenaga listrik $20 \mathrm{kV}$ yang bersumber dari Gardu Induk Pesanggaran dengan data sebagai berikut:

Panjang Jaringan

Jenis Penghantar

: $16.976 \mathrm{~m}$

: NA2XSEBY $240 \mathrm{~mm}^{2}$, MVTIC 150 $\mathrm{mm}^{2}$, AAAC $150 \mathrm{~mm}^{2}$.

Jumlah Trafo

: 72 Unit

Total Daya Trafo

: $15.170 \mathrm{kVA}$

: 4.091 Pelanggan

: $3.873,7 \mathrm{kVA}$

\subsection{Analisis Rugi-Rugi Daya pada Penyulang \\ Serangan}

Berdasarkan analisis rugi-rugi daya yang telah dilakukan pada kondisi Penyulang Serangan tanpa interkoneksi DG diperoleh rugi-rugi daya sebesar $40 \mathrm{~kW}$ atau $1,21 \%$ dari total suplai daya sebesar $3.307 \mathrm{~kW}$. Dengan interkoneksi DG sebesar $352,75 \mathrm{~kW}$ pada Penyulang Serangan maka diperoleh hasil penurunan rugi-rugi daya sebesar $38,1 \mathrm{~kW}$. Perbandingan besarnya rugi-rugi daya pada Penyulang Serangan tanpa interkoneksi DG dan terinterkoneksi DG dapat dilihat pada tabel 3 berikut:

Tabel 2. Perbandingan Nilai Rugi-Rugi Daya Penyulang Serangan

\begin{tabular}{|c|c|}
\hline \multicolumn{2}{|c|}{ Rugi-Rugi Daya $(\mathbf{k W})$} \\
\hline Tanpa DG & Dengan DG \\
\hline 40 & 38,1 \\
\hline
\end{tabular}

Interkoneksi DG dilakukan ke LBS PLTS yang ada pada Penyulang Serangan dengan jarak antara LBS PLTS dengan lokasi DG adalah $655 \mathrm{~m}$. Lokasi interkoneksi tersebut merupakan lokasi terdekat untuk melakukan interkoneksi DG ke Penyulang Serangan. Penurunan rugi-rugi daya yang mampu dihasilkan dengan interkoneksi DG adalah sebesar 1,9 $\mathrm{kW}$ atau $4,75 \%$ dari total rugi-rugi daya yang terjadi pada kondisi Penyulang Serangan tanpa interkoneksi DG.

\subsection{Analisis Lokasi Interkoneksi Distributed Generation untuk Memperoleh Rugi-Rugi Daya Terendah}

Analisis Lokasi interkoneksi DG dilakukan dengan mempersentasekan panjang saluran mulai dari $25 \%, 50 \%$, $75 \%, 80 \%-90 \%$, dan $90 \%,-100 \%$ dari total panjang saluran Penyulang Serangan. Berdasarkan hasil simulasi diperoleh penurunan rugi-rugi daya untuk setiap lokasi interkoneksi DG yang ditampilkan pada tabel 4.

Berdasarkan tabel 4 dapat diketahui bahwa lokasi terdekat untuk melakukan interkoneksi DG ke Penyulang Serangan berada pada jarak $25 \%$ dari total panjang saluran dengan rugirugi yang dihasilkan adalah sebesar $38,1 \mathrm{~kW}$ atau $4,75 \%$ dari total rugi-rugi daya yang terjadi pada Penyulang Serangan tanpa interkoneksi DG. Sedangkan lokasi terbaik dengan rugirugi daya terendah berada pada pada titik $80 \%$ dari total panjang saluran yang mampu menghasilkan rugi-rugi daya

terendah yaitu $35,3 \mathrm{~kW}$ atau penurunan sebesar $11,75 \%$ dari total rugi-rugi daya yang terjadi pada Penyulang Serangan tanpa interkoneksi DG. Gambar 5 menunjukkan penurunan nilai rugi-rugi daya dari setiap lokasi interkoneksi DG.

Tabel 3. Perbandingan Nilai Rugi-Rugi Daya dari Setiap Lokasi Interkoneksi DG

\begin{tabular}{|c|c|c|c|c|}
\hline No. & $\begin{array}{l}\text { Lokasi Dari Grid } \\
\qquad(\%)\end{array}$ & $\begin{array}{c}\text { Panjang } \\
\text { Penghantar } \\
\text { Dari DG (m) }\end{array}$ & $\begin{array}{c}\text { Rugi-Rugi } \\
\text { Pada } \\
\text { Penghantar } \\
\text { DG (kW) }\end{array}$ & $\begin{array}{l}\text { Rugi-Rugi } \\
\text { Daya (kW) }\end{array}$ \\
\hline 1 & Tanpa DG & - & - & 40 \\
\hline 2 & 25 & 655 & 0,1 & 38,1 \\
\hline 3 & 50 & 4.898 & 0,7 & 35,5 \\
\hline 4 & 75 & 9.143 & 1,2 & 35,4 \\
\hline 5 & 80 & $9.991,8$ & 1,3 & 35,3 \\
\hline 8 & 81 & $10.161,56$ & 1,4 & 35,3 \\
\hline 7 & 82 & $10.331,32$ & 1,4 & 35,3 \\
\hline 8 & 83 & $10.501,08$ & 1,4 & 35,3 \\
\hline 8 & 84 & $10.670,84$ & 1,4 & 35,3 \\
\hline 10 & 85 & $10.840,8$ & 1,5 & 35,3 \\
\hline 11 & 86 & $11.010,38$ & 1,5 & 35,3 \\
\hline 12 & 87 & $11.180,12$ & 1,5 & 35,3 \\
\hline 13 & 88 & $11.348,88$ & 1,5 & 35,3 \\
\hline 14 & 89 & $11.519,84$ & 1,5 & 35,3 \\
\hline 15 & 80 & $11.889,4$ & 1,6 & 35,3 \\
\hline 18 & 81 & $11.859,18$ & 1,6 & 35,4 \\
\hline 17 & 82 & $12.028,92$ & 1,6 & 35,4 \\
\hline 18 & 93 & $12.198,68$ & 1,6 & 35,4 \\
\hline 18 & 84 & $12.368,44$ & 1,7 & 35,5 \\
\hline 20 & 85 & $12.538,2$ & 1,7 & 35,5 \\
\hline 21 & 96 & 12.707 .98 & 1,7 & 35,5 \\
\hline 22 & 97 & $12.877,72$ & 1,7 & 35,5 \\
\hline 23 & 98 & $13.047,48$ & 1,7 & 35,8 \\
\hline 24 & 98 & $13.217,24$ & 1,8 & 35,8 \\
\hline 25 & 100 & 13.387 & 1,8 & 35,8 \\
\hline
\end{tabular}

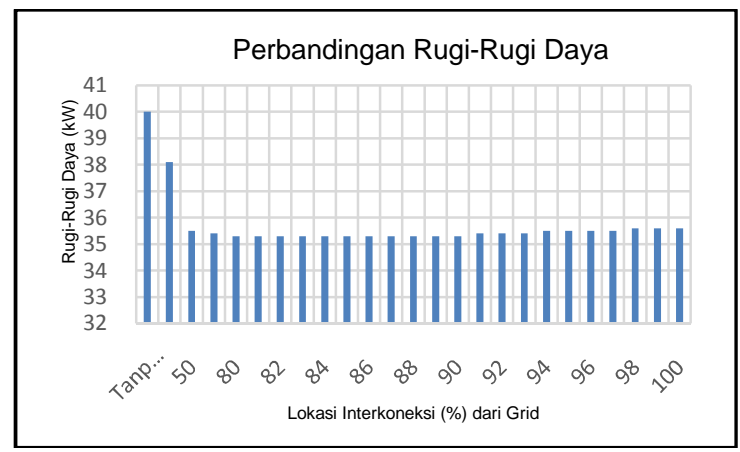

Gambar 3. Grafik Perbandingan Rugi-Rugi Daya dari Setiap Lokasi Interkoneksi DG

\subsection{Analisis Tingkat Keandalan Penyulang Serangan}

Analisis tingkat keandalan pada Penyulang Serangan tanpa interkoneksi DG menggunakan reliability assessment ditampil-kan dalam suatu indeks keandalan yang 
menggambarkan tingkat keandalan dari Penyulang Serangan. Berdasarkan simulasi yang telah dilakukan indeks keandalan pada Penyulang Serangan yang diperoleh yaitu SAIFI = 1,4195 gangguan/pelanggan/tahun; SAIDI = 2,8035 $\mathrm{jam} /$ pelanggan/tahun; CAIDI = 1,975 jam/gangguan; ASAI = $0,9997 \mathrm{pu}$; dan ASUI $=0.00032 \mathrm{pu}$. Dengan interkoneksi DG sebesar 352,75 kW pada Penyulang Serangan maka diperoleh indeks keandalan baru yang menggambarkan tingkat keandalan dari Penyulang Serangan. Perbandingan indeks keandalan pada Penyulang Serangan tanpa interkoneksi DG dan terinterkoneksi DG dapat dilihat pada tabel 3 berikut:

Tabel 4. Nilai Indeks Keandalan Penyulang Serangan

\begin{tabular}{|c|c|c|}
\hline Indeks Keandalan & Tanpa DG & Dengan DG \\
\hline $\begin{array}{c}\text { SAIFI } \\
\text { (Gangguan/Pelanggan/Tahun) }\end{array}$ & 1,4195 & 0,5959 \\
\hline $\begin{array}{c}\text { SAIDI } \\
\text { (Jam/Pelanggan/Tahun) }\end{array}$ & 2,8035 & 1,4388 \\
\hline CAIDI (jam/Gangguan) & 1,975 & 2,414 \\
\hline ASAI (pu) & 0.9997 & 0.9998 \\
\hline ASUI (pu) & 0.00032 & 0.00016 \\
\hline
\end{tabular}

Berdasarkan hasil simulasi yang ditunjukkan pada tabel 5 dapat diketahui bahwa terjadi peningkatan keandalan pada Penyulang Serangan yang terlihat pada perolehan nilai indeks keandalah yang baru. Dengan interkoneksi DG ke Penyulang Serangan diperoleh nilai indeks keandalan SAIFI $=0,5959$ gangguan/pelanggan/tahun; SAIDI $=1,4388 \mathrm{jam} /$ pelanggan /tahun; CAIDI = 2,414 jam/ganguan; $\mathrm{ASAI}=0.9998 \mathrm{pu}$; dan ASUI $=0.00016 \mathrm{pu}$. Perbandingan indeks keandalan Penyulang Serangan tanpa interkoneksi DG dan dengan interkoneksi DG dapat dilihat pada tabel 5.

DG dapat dilihat pada tabel 5.

\subsection{Analisis Lokasi Interkoneksi Distributed Generation Untuk Memperoleh Tingkat Keandalan Tertinggi}

Berdasarkan analisis yang telah dilakukan mengenai pengaruh interkoneksi DG terhadap keandalan, maka dilakukan analisis lokasi interkoneksi yang mampu menghasilkan indeks keandalan baru dan merupakan lokasi dengan tingkat keandalan tertinggi. Dengan simulasi menggunakan tools reliability assessmen diperoleh hasil seperti yang ditunjukkan pada tabel 6 .

Berdasarkan tabel 5 dapat diketahui bahwa lokasi dengan tingkat keandalan tertinggi yaitu pada jarak $97 \%$ dari total panjang saluran Penyulang Serangan. Pada lokasi tersebut diperoleh indeks keandalan baru yaitu dengan indeks SAIFI = 0,1 gangguan/pelanggan/tahun; SAIDI $=1,4150$ jam/pelanggan/tahun; CAIDI = 14,1520 jam/ ganguan; ASAI $=0.9998 \mathrm{pu}$; dan ASUI $=0.00016 \mathrm{pu}$.

Jika dibandingkan dengan kondisi Penyulang Serangan tanpa interkoneksi DG maka terjadi peningkatan keandalan yang lebih besar yang terlihat dari perubahan masing-masing indeks keandalan yang digambarkan dalam grafik-grafik berikut:
Tabel 5. Perbandingan Nilai Indeks Keandalan dari Setiap Lokasi Interkoneksi DG

\begin{tabular}{|c|c|c|c|c|c|c|c|}
\hline \multirow{2}{*}{ No. } & \multirow{2}{*}{$\begin{array}{l}\text { Lokasi } \\
\text { Dari Grid } \\
(\%)\end{array}$} & \multirow{2}{*}{$\begin{array}{c}\text { Panjang } \\
\text { Penghan } \\
\text { tar } \\
\text { Dari DG } \\
\text { (m) }\end{array}$} & \multicolumn{5}{|c|}{ Indeks Keanclalan } \\
\hline & & & $\begin{array}{c}\text { SAIFI } \\
\text { (ficustlyr) }\end{array}$ & $\underset{\text { (hrlcustyr) }}{\text { SAIDI }}$ & $\begin{array}{c}\text { CAIDI } \\
\text { (hrif) }\end{array}$ & $\begin{array}{c}\text { ASA } \\
\text { (pu) }\end{array}$ & $\begin{array}{l}\text { ASUI } \\
\text { (pu) }\end{array}$ \\
\hline 1 & $\begin{array}{c}\text { Tanpa } \\
\text { DG }\end{array}$ & - & 1.4195 & 2.8035 & 1.975 & 0.9997 & 0.00032 \\
\hline 2 & 25 & 655 & 0.5959 & 1.4388 & 2.414 & 0.9998 & 000016 \\
\hline 3 & 50 & 4899 & 0.2758 & 1.4775 & 5.3570 & 0.9998 & 0.00017 \\
\hline 4 & 75 & 9143 & 0.2200 & 1.4775 & 3.7160 & 0.9998 & 0.00017 \\
\hline 5 & 80 & 9991.8 & 0.1656 & 1.4775 & 3.9200 & 0.9998 & 0.00017 \\
\hline 6 & 81 & 10161.56 & 0.1552 & 1.4775 & 9.5210 & 0.9998 & 0.00017 \\
\hline 7 & 82 & 10331.32 & 0.1435 & 1.4775 & 10.2940 & 0.9998 & 000017 \\
\hline 8 & 83 & 10501.08 & 0.1435 & 1.4775 & 10.2940 & 0.9998 & 000017 \\
\hline 9 & 84 & 10670.84 & 0.1288 & 1.4775 & 11.4690 & 0.9998 & 0.00017 \\
\hline 10 & 85 & 10840.6 & 0.1288 & 1.4775 & 11.4690 & 0.9998 & 000017 \\
\hline 11 & 86 & 11010.36 & 0.1208 & 1.4775 & 12.2300 & 0.9998 & 000017 \\
\hline 12 & 87 & 11180.12 & 0.1123 & 1.4520 & 12.9260 & 0.9998 & 000017 \\
\hline 13 & 88 & 11349.88 & 0.1123 & 1.4520 & 12.9260 & 0.9998 & 0.00017 \\
\hline 14 & 89 & 11519.64 & 0.1116 & 1.4498 & 12.9930 & 0.9998 & 0.00017 \\
\hline 15 & 90 & 11689.4 & 0.1116 & 1.4498 & 12.9930 & 0.9998 & 0.00017 \\
\hline 16 & 91 & 11859.16 & 0.1121 & 1.4514 & 12.9470 & 0.9998 & 0.00017 \\
\hline 17 & 92 & 12028.92 & $0.107 ?$ & 1.4380 & 13.3570 & 0.9998 & 000016 \\
\hline 18 & 93 & 12198.68 & 0.1012 & 1.4185 & 14.0220 & 0.9988 & 000016 \\
\hline 19 & 94 & 12368.44 & 0.1012 & 1.4185 & 14.0220 & 0.9998 & 000016 \\
\hline 20 & 95 & 12538.2 & 0.1001 & 1.4155 & 14.1340 & 0.9998 & 0.00016 \\
\hline 21 & 96 & 12707.96 & 0.1001 & 1.4155 & 14.1340 & 0.9998 & 0.00016 \\
\hline 22 & 97 & 12877.72 & 0.1000 & 1.4150 & 14.1520 & 0.9988 & 0.00016 \\
\hline 23 & 98 & 13047.48 & 0.1000 & 1.4150 & 14.1520 & 0.9998 & 000016 \\
\hline 24 & 99 & 13217.24 & 0.1000 & 1.4150 & 14.1520 & 0.9998 & 000016 \\
\hline 25 & 100 & 13387 & 0.1000 & 1.4150 & 14.1520 & 0.9998 & 000016 \\
\hline
\end{tabular}

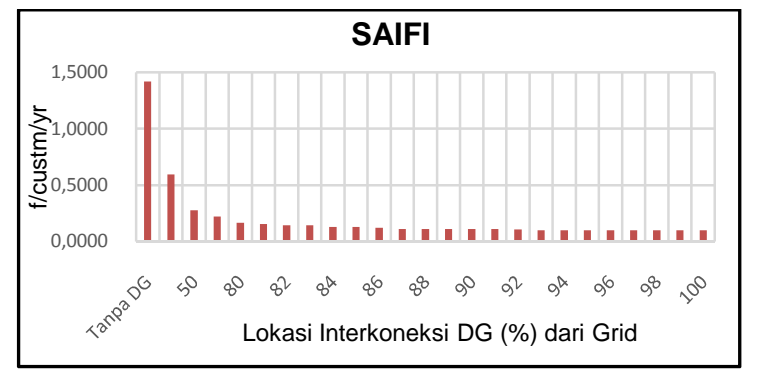

Gambar 4. Grafik Perbandingan Indeks Keandalan SAIFI dari Setiap Titik Lokasi Interkoneksi DG

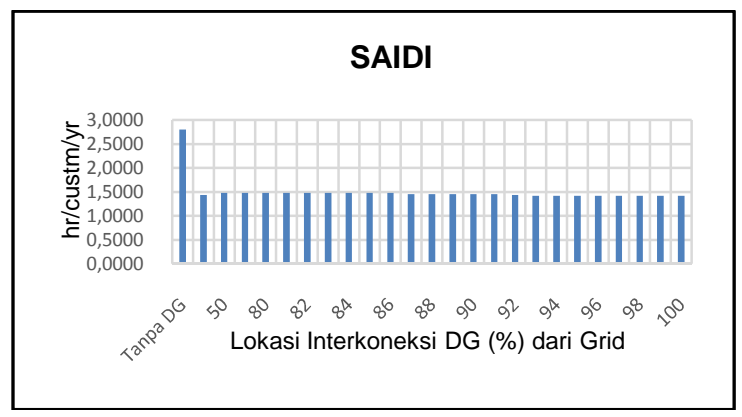

Gambar 5. Grafik Perbandingan Indeks Keandalan SAIDI dari Setiap Titik Lokasi Interkoneksi DG 


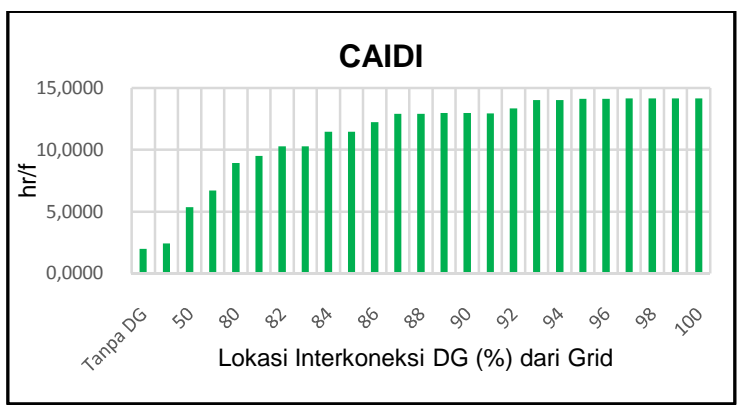

Gambar 6. Grafik Perbandingan Indeks Keandalan CAIDI dari Setiap Titik Lokasi Interkoneksi DG

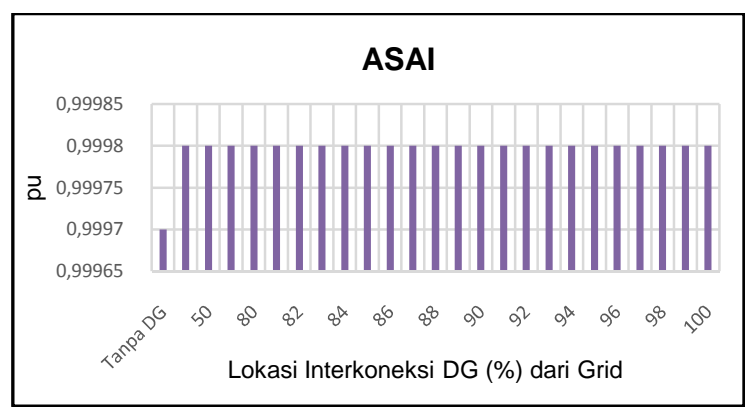

Gambar 7. Grafik Perbandingan Indeks Keandalan ASAI dari Setiap Titik Lokasi Interkoneksi DG

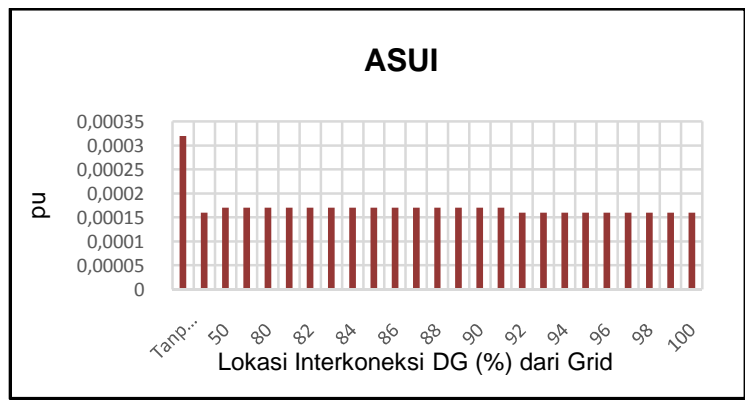

Gambar 8. Grafik Perbandingan Indeks Keandalan ASUI dari Setiap Titik Lokasi Interkoneksi DG

\subsection{Lokasi Interkoneksi DG Pada Penyulang Serangan dengan Nilai Rugi-Rugi Daya Terendah dan Keandalan Tertinggi}

Berdasarkan analisis lokasi interkoneksi DG yang telah dilakukan, rugi-rugi daya terendah diperoleh pada jarak $80 \%$ dan untuk lokasi dengan indeks keandalan terbaik diperoleh pada jarak $97 \%$. Berikut hasil simulasi ditunjukkan pada tabel 6.

Berdasarkan tabel 6 dapat diketahui titik interkoneksi DG yang mampu menghasilkan nilai rugi-rugi daya yang rendah dan indeks keandalan yang tinggi yaitu pada jarak $97 \%$ dari total panjang saluran Penyulang Serangan. Hal ini dapat dilihat dengan nilai rugi-rugi daya yang dihasilkan pada titik tersebut sebesar $35,5 \mathrm{~kW}$ yang memiliki selisih $0,2 \mathrm{~kW}$ dengan lokasi interkoneksi DG pada jarak $80 \%$ yang merupakan lokasi dengan hasil rugi-rugi daya terendah yaitu $35,3 \mathrm{~kW}$. Sedangkan indeks keandalan pada titik interkoneksi DG jarak $97 \%$ merupakan lokasi dengan tingkat keandalan tertinggi. Pada titik interkoneksi dengan jarak 97\% dari total panjang saluran diperoleh rugi-rugi daya sebesar $35,5 \mathrm{~kW}$ dan indeks keandalan baru dengan indeks SAIFI $=0,1$ gangguan/pelanggan/tahun; SAIDI $=1,4150 \mathrm{jam} /$ pelanggan $/$ tahun; CAIDI $=14,1520$ jam/gangguan; $\mathrm{ASAI}=0,9998 \mathrm{pu}$; dan ASUI $=0,00016 \mathrm{pu}$.

Tabel 6. Nilai Rugi-Rugi Daya dan Indeks Keandalan dari Setiap Lokasi Interkoneksi DG

\begin{tabular}{|c|c|c|c|c|c|c|c|c|}
\hline \multirow{2}{*}{ No } & \multirow{2}{*}{$\begin{array}{l}\text { Lokasi } \\
\text { Dari Grid } \\
(\%)\end{array}$} & \multirow{2}{*}{$\begin{array}{c}\text { Panjang } \\
\text { Penghan } \\
\text { tar } \\
\text { Dari DG } \\
\text { (m) }\end{array}$} & \multirow{2}{*}{$\begin{array}{l}\text { Rugi- } \\
\text { Rugi } \\
\text { Daya } \\
\text { (kW) }\end{array}$} & \multicolumn{5}{|c|}{ Indeks Keandalan } \\
\hline & & & & $\begin{array}{c}\text { SAIFI } \\
\text { [fieust//r! }\end{array}$ & $\begin{array}{c}\text { SAID| } \\
\text { (hrlcustiyr) }\end{array}$ & $\begin{array}{l}\text { CAID| } \\
\text { (hrif) }\end{array}$ & $\begin{array}{c}\text { ASA } \\
\text { (pu) }\end{array}$ & $\begin{array}{c}\text { ASUI } \\
\text { (pu) }\end{array}$ \\
\hline , & Tarpa DG & . & 40 & 1.4196 & $2.803 E$ & 1.975 & 0.9697 & 0.00032 \\
\hline 2 & 25 & 855 & 33.1 & 0.5958 & 1.4338 & $2.4: 4$ & 0.9998 & 0.00016 \\
\hline 3 & 5] & 4839 & 35.5 & 0.2758 & $1.477 \varepsilon$ & 5.3570 & 0.9698 & 0.00017 \\
\hline 4 & 75 & 8143 & 35.4 & 0.2200 & 1.4775 & 3.7130 & 0.9998 & 0.00017 \\
\hline 5 & 81 & 9991.3 & 35.3 & 0.1658 & $1.477 \varepsilon$ & 3.9230 & 0.9688 & 0.00017 \\
\hline 8 & 81 & 0161.56 & 35.3 & 0.1552 & $1.477 E$ & 9.5210 & 0.9698 & 0.00017 \\
\hline 7 & 82 & 0331.32 & 35.3 & 0.1435 & $1.477 \varepsilon$ & 10.2840 & 0.9698 & 0.00017 \\
\hline 8 & 83 & $0501 . J 8$ & 35.3 & 0.1435 & $1.477 \varepsilon$ & 102840 & 0.9698 & 0.00017 \\
\hline 8 & 84 & 0670.34 & 35.3 & 0.1288 & $1.477 \varepsilon$ & 11.4890 & 0.9698 & 0.00017 \\
\hline 10 & 85 & 108406 & 35.3 & 0.1288 & $1.477 \varepsilon$ & 11.4890 & 0.9698 & 0.00017 \\
\hline 11 & 83 & 1010.36 & 35.3 & 0.1208 & $1.477 \varepsilon$ & 12.2300 & 0.9698 & 0.00017 \\
\hline 12 & 87 & 1180.12 & 35.3 & 0.1123 & $1.452 C$ & 12.9260 & 0.9698 & 0.00017 \\
\hline 13 & 83 & 1349.38 & 35.3 & 0.1123 & $1.452 C$ & 12.9260 & 0.9698 & 0.00017 \\
\hline 14 & 89 & 11519.34 & 35.3 & 0.1118 & 1.4498 & 129830 & 0.9698 & 0.00017 \\
\hline 15 & 8J & 118894 & 35.3 & 0.1118 & 1.4498 & 12.9830 & 0.9698 & 0.00017 \\
\hline 13 & 91 & 11859.16 & 35.4 & 0.1121 & 1.4514 & 12.9470 & 0.9698 & 0.00017 \\
\hline 17 & 92 & 2028.32 & 35.4 & 0.1077 & $1.433 C$ & 13.3570 & 0.9698 & 0.00016 \\
\hline 18 & 93 & $2188.3 E$ & 35.4 & 0.1012 & $1.413 E$ & 14.0220 & 0.9698 & 0.00016 \\
\hline 18 & 84 & 2288.44 & 35.5 & 0.1012 & $1.413 E$ & 14.0220 & 0.9698 & 0.00016 \\
\hline 20 & 95 & 125382 & 35.5 & 0.1001 & $1.415 E$ & 14.1340 & 0.9698 & 0.00016 \\
\hline 21 & 93 & 2707.36 & 35.5 & 0.1001 & $1.415 E$ & 14.1340 & 0.9698 & 0.00016 \\
\hline 22 & 97 & 2877.72 & 35.5 & 0.1000 & $1.415 C$ & 14.1520 & 0.9698 & 0.00016 \\
\hline 23 & 83 & $3047.4 \varepsilon$ & 35.8 & 0.1000 & $1.413 \mathrm{C}$ & 14.1520 & 0.9698 & 0.00018 \\
\hline 24 & 97 & 3217.24 & 35.6 & 0.1000 & 1.4150 & 14.1520 & 0.9698 & 0.00018 \\
\hline 25 & 100 & 13387 & 35.8 & 0.1000 & 1.4150 & 14.1520 & 0.9898 & 0.00016 \\
\hline
\end{tabular}

\section{SIMPULAN}

Berdasarkan hasil analisis dan pemba-hasan yang telah dilakukan, maka dapat ditarik simpulan bahwa interkoneksi DG pada Penyulang Serangan mampu menghasilkan penurunan rugi-rugi daya dan meningkatkan keandalan pada penyulang dengan lokasi interkoneksi terbaik untuk memperoleh rugi-rugi daya yang rendah dan tingkat keandalan yang tinggi adalah pada jarak $97 \%$ dari total panjang saluran. Pada lokasi tersebut diperoleh penurunan rugi-rugi daya sebesar $4,5 \mathrm{~kW}$ atau $11,25 \%$ dari total rugirugi daya tanpa inter-koneksi DG dan penurunan indeks SAIFI dan SAIDI masing-masing menjadi 0,1 gangguan/pelanggan/tahun dan $1,4150 \mathrm{jam} /$ pelanggan/tahun. 


\section{DAFTAR PUSTAKA}

[1] Putra, I. G. N. Dion Adi., Giriantari I. A. D., Ariastina, W.G. 2015. Analisis Rugi Daya pada Penyulang Bangli dengan Beroperasinya PLTS Kayubihi. Jurnal Teknologi Elektro Vol. 14, No. 1, Januari. Universitas Udayana.

[2] Sunanda, Wahri. 2013. Perbaikan Keandalan Sistem Melalui Pemasangan Distributed Generation. Bangka Belitung: Jurnal Ilmiah Foristek Vol.3, No.2, September. Universitas Bangka Belitung.

[3] Ardrianti, Irani S. 2008. Studi Aliran Daya Tiga Fasa Untuk Sistem Distribusi Dengan Metode Pendekatan Langsung.Jurnal Teknik A Vol. 2, No. 29,April.Teknik Elektro Universitas Andalas Padang.

[4] Glover, J. Duncan., Sarma, Mulukutla S., Overbye, Thomas J. 2010. Power System Design. $5^{\text {th }}$ edition. United State: Cengage Learning.

[5] Winantara, Gesta., Hartati, Rukmi Sari., Sukerayasa, I Wyn. 2013. Pengaruh Injeksi Daya Aktif Terhadap Keandalan Penyulang. Jurnal Teknologi Elektro Vol. 12, No. 1, Januari. Universitas Udayana.

[6] Gonen, Turan. 2008. Electric Power Distribution System Engineering. $2^{\text {nd }}$ edition. Sacramento: CRC Press. 